\title{
Conserving coral reef organisms that lack larval dispersal: are networks of Marine Protected Areas good enough?
}

\author{
Paolo Momigliano ${ }^{1,2}$, Robert Harcourt ${ }^{2 *}$ and Adam Stow ${ }^{1}$ \\ ${ }^{1}$ Conservation Genetics Lab, Department of Biological Sciences, Macquarie University, North Ryde, NSW, Australia \\ ${ }^{2}$ Marine Predator Research Group, Department of Biological Sciences, Macquarie University, North Ryde, NSW, Australia \\ ${ }^{*}$ Correspondence: robert.harcourt@mq.edu.au
}

Edited by:

Graeme Clive Hays, Deakin University, Australia

Reviewed by:

Gail Schofield, Deakin University, Australia

Mark Meekan, Australian Institute of Marine Science, Australia

Keywords: marine reserves, coral reefs, conservation, connectivity, corridors

\section{INTRODUCTION}

Coral reef ecosystems are under increasing threat due to the synergistic effects of habitat destruction, overfishing, eutrophication and climate change (Hughes et al., 2003, 2007; Hoegh-Guldberg et al., 2007). In response to these threats, management strategies that implement networks of Marine Protected Areas (MPAs) have gained momentum in the past few decades. Networks of MPAs can protect coral reef biodiversity from anthropogenic impacts either by eliminating the impacts of overfishing and habitat destruction, or by increasing ecosystem resilience to other anthropogenic disturbances (Russ and Zeller, 2003; McCook et al., 2010).

For networks of MPAs to be effective they must meet three key elements. Individual MPAs must be (1) partially self-seeding (Almany et al., 2007, 2009), (2) adequately connected to other MPAs via dispersal (Jones et al., 2007; Almany et al., 2009), and (3) they must protect target organisms during life stages when they are most vulnerable to anthropogenic impact (Zeller and Russ, 1998). Accordingly, MPAs should be large enough to encompass individual home ranges of the target species and to ensure a portion of the larvae produced within a MPA settles within its boundaries (Almany et al., 2009). Furthermore, networks of MPAs must ensure genetic and demographic connectivity between protected areas. Connectivity is defined as the exchange of individuals between populations. Connectivity bolsters local resilience to stochastic demographic fluctuations and in so doing, minimizes genetic erosion, the risk of inbreeding depression and ultimately maximizes adaptive potential (Almany et al., 2009).

Here we discuss how different life history strategies may affect the feasibility of achieving the three requirements for effective long-term conservation (selfseeding, connectivity, and protection). While sedentary organisms with a pelagic larval phase (most reef fishes and invertebrates), readily achieve this trinity (Planes et al., 2009), animals where dispersal only occurs as adults inevitably fail to meet all three requirements simultaneously (Figure 1). Here we propose a potential solution focusing on incorporating information on how habitat shapes adult dispersal to increase connectivity within networks of MPAs.

\section{PELAGIC LARVAL DISPERSAL}

Many reef organisms have a bipartite life cycle: they have pelagic larvae and become sedentary adults. By definition, these adults have often limited homeranges, and accordingly they are effectively protected even within relatively small MPAs, i.e., those encompassing single coral reefs (Zeller and Russ, 1998; Lee et al., 2014). Within a single species, larval dispersal often has large variance with some larvae settling close by, within their natal reef, while others disperse to reefs that may be hundreds of $\mathrm{km}$ away (Jones et al., 2009). Larvae may settle on their natal reefs because they detect good habitat through olfactory cues (Gerlach et al., 2007), or simply because they are retained by local oceanographic features such as eddies and density fronts (Sponaugle et al.,
2002). The results of such high variance in dispersal is that local reefs may be effectively self-seeding (Almany et al., 2007), while simultaneously maintaining genetic and demographic connectivity with other MPAs (Jones et al., 2009). When their design is most effective, no-take zones may export larvae to fished areas and in so doing help sustain fisheries outside MPAs (Harrison et al., 2012).

Although there is large variance in the duration of the pelagic larval stage, many species of reef fishes show similar patterns of self-recruitment and dispersal with the result that larval dispersal for many taxa ranges from a few meters to $10 \mathrm{~s}$ of $\mathrm{km}$ (Jones et al., 2009). Accordingly, for many reef fishes, within a network of MPAs, between-reserve distances of $<50 \mathrm{~km}$ will be sufficient to ensure connectivity (Almany et al., 2009).

\section{ADULT DISPERSAL}

While extant MPAs are highly effective for reef fish with pelagic larvae, not all reef organisms share that life cycle. Entire groups of taxa, some of which play pivotal roles in coral reef ecosystems produce highly precocial young with a high degree of natal reef fidelity, for example, most elasmobranchs (Last and Stevens, 2009) and sea snakes (Voris and Jayne, 1979; Ward, 2001). Others, such as many sepiids and octopods, may produce a large number of eggs, but the juveniles that hatch from them often do not disperse widely due to their benthic habits (Boyle, 1990). These life history traits result in important components of biodiversity not being optimally protected by networks of 

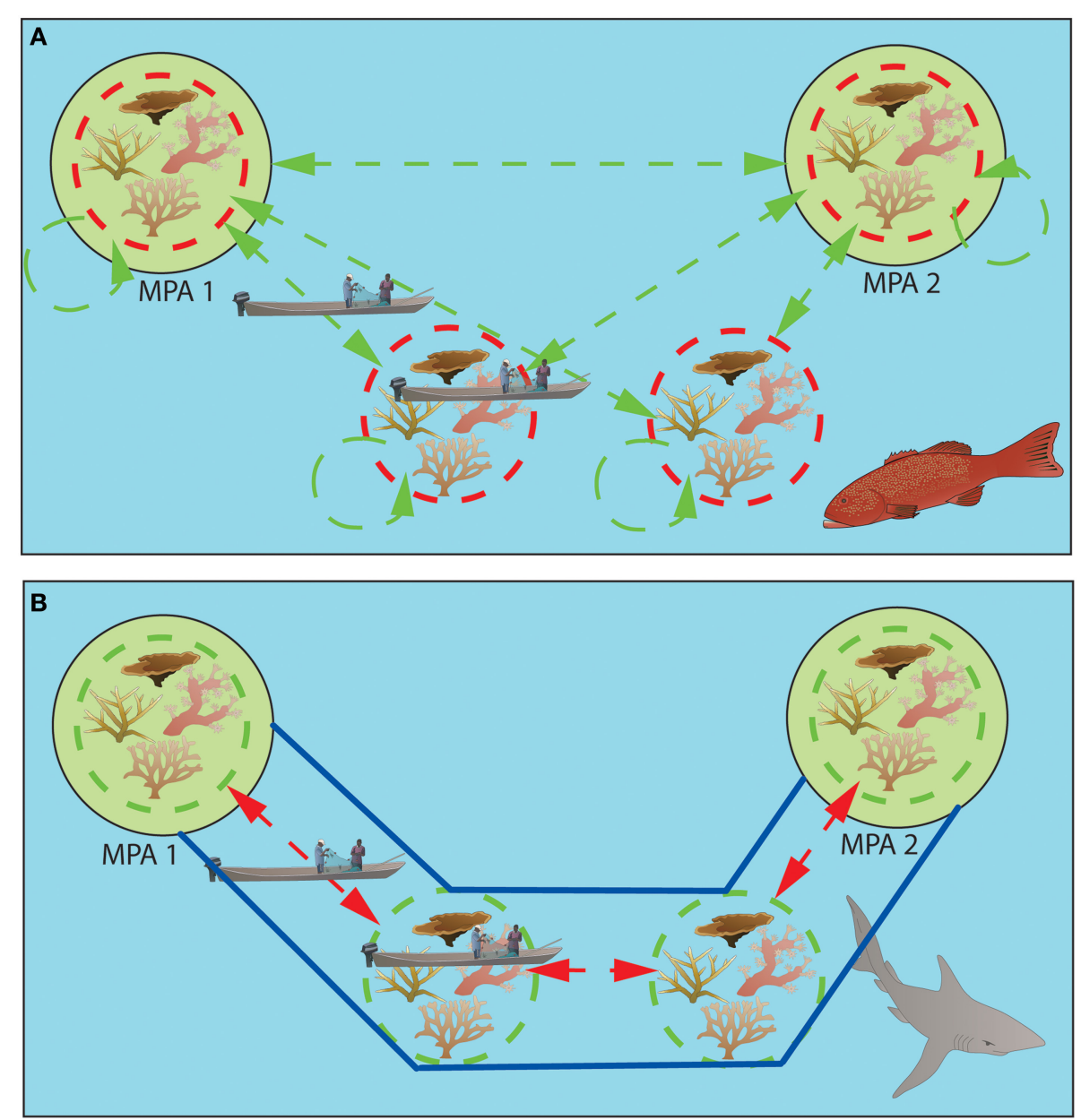

FIGURE 1 | Consequences of different life history strategies on the effectiveness of networks of MPAs. (A) larval dispersal, sedentary adults. Adult home range is shown in red dashed circles, larval dispersal in dashed green lines. Adults are effectively protected by MPAs (shown in green), and connectivity is ensured via larval dispersal, while a portion of the larvae settles within natal reefs. MPAs also provide recruitment subsidies to fished reefs. (B) Adult dispersal, juveniles with site fidelity. Juvenile home range is shown in green dashed circles, adult dispersal by red dashed lines. While juveniles are protected by the MPAs, adults move outside of the reserves' boundaries, crossing to neighboring reefs where they are subject to fishing pressure. A potential solution is the establishment of connectivity corridors (shown in blue), allowing for protected movement of animals between no-take zones.
MPAs. Depending on mobility at the adult stage, these taxa will either be largely disconnected from other reef systems, or spend part of their lives unprotected (Heupel et al., 2010), with the prospect of self-seeding not being sufficient for any particular MPAs to be demographically independent.

In organisms with pelagic larvae, dispersal occurs at a stage in which mortality rates are extremely high and this mortality is offset by the production of thousands to millions of larvae. The mortality rates of adult rays, sharks and sea snakes in the absence of anthropogenic threats are on the other hand comparatively low (Fry et al., 2001; Ward, 2001; Last and
Stevens, 2009). As a result, their potential exposure to fishing pressure when moving between MPAs is of far greater consequence. To muddy the waters for effective conservation even further, the capacity for adult dispersal also varies substantially. For example, the olive sea snake Aipysurus laevis rarely ventures far from home reefs and has a home range of less than two $\mathrm{km}^{2}$ (Burns and Heatwole, 1998) while adult gray reef sharks (Carcharhinus amblyrhynchos) may move $>100 \mathrm{~km}$ in a few days (Heupel et al., 2010) and turtles may traverse thousands of kilometers between reproductive eisodes (Hays et al., 2014). To provide optimum protection for taxa with such diverse dispersal strategies is extremely complex in the absence of detailed information on how and where species disperse.

\section{THE CHALLENGE OF PROTECTING CORAL REEF PREDATORS}

Although the number of species with adult dispersal are few compared to the diversity of coral reef organisms with pelagic larvae (Tittensor et al., 2010), the proportion of the biomass they account for in healthy reefs is extraordinary. Recent studies suggest that pristine coral reefs have top-heavy biomass pyramids, and apex predators may overwhelm fish assemblages (Sandin et al., 2008; Friedlander et al., 2014). In remote areas where little fishing 
has occurred, reef sharks may account for more than $60 \%$ of top predator biomass (Friedlander et al., 2014). Crucially, their removal may have substantial top-down effects on the whole ecosystem (Ruppert et al., 2013; Heithaus et al., 2014). This points to the loss of reef sharks being a significant issue for long term sustainability of healthy reef ecosystems, because a very large proportion of the fish biomass may not be optimally protected, even by the most carefully managed networks of MPAs.

MPAs that work best for sharks are very large $\left(>100 \mathrm{~km}^{2}\right)$ reserves around isolated oceanic islands where no-take policies are effectively enforced (Edgar et al., 2014). Under these conditions animals have very little chance of moving out of the reserve because they are surrounded by large stretches of unsuitable habitats, and there is strong evidence that reef sharks will then exhibit a high degree of site fidelity (Field et al., 2011; Barnett et al., 2012). Unfortunately very few such reserves exist. Even though a number of giant marine reserves and shark sanctuaries have been established in recent years, they vary greatly in terms of which fishing activities are permitted within their boundaries (Cressey, 2011; Pala, 2013). In the long-term giant reserves are likely to play an important role in conserving the biodiversity of wide ranging animals (Hays et al., 2014), but there are enormous challenges both in terms of enforcement and monitoring which limit their effectiveness (Cressey, 2011; Pala, 2013). In multiple use MPA networks, where "no take" areas are not clearly isolated from areas open to fisheries by large stretches of unsuitable habitat, reef sharks may not be constrained to the MPAs. For example, reefs that are very close are likely perceived as continuous habitats; in these conditions reef sharks may move continuously between neighboring reefs crossing the boundaries of different management zones (Heupel et al., 2010). As distance between reefs increases, gray reef sharks exhibit higher site fidelity, but a large proportion of them still hop from reef to reef, moving to (or through) unprotected areas (Espinoza et al., 2015). This may be a problem if most reefs in a network of MPAs are small and geographically very close to each other. This is the case in the Great Barrier Reef (GBR)
Marine Park in Australia, where the majority of reefs are small $\left(<10 \mathrm{~km}^{2}\right)$ and separated by distances of $<2 \mathrm{~km}$ (Almany et al., 2007).

\section{UNDERSTANDING CONNECTIVITY IN ADULT DISPERSERS: LESSONS FROM LANDSCAPE GENETICS}

For taxa with high adult mobility one potential solution is to include corridors in the design of networks of MPAs, thereby allowing for movement of animals between no-take zones and extending protection for animals with wider home-ranges. Such corridors need not be designated "all-encompassing no-take" policies, but could be targeted specifically to ensure that groups of animals with similar habitat preferences and dispersal abilities are provided effective protection. The concept that connectivity corridors should be included in MPAs networks is fairly new and has so far been advocated nearly exclusively for migratory species en route to protected foraging and breeding grounds, such as sea turtles, pinnipeds, and cetaceans (Hooker et al., 2011; Pendoley et al., 2014). Similar approaches for the co-management of sympatric species of importance have been previously advocated for other iconic animals, such as dugongs and sea turtles (Gredzens et al., 2014). Here we argue that such an approach may even be essential for the conservation of meso and apex predators that do not undertake large migrations.

To be effective, designing corridors requires knowledge of how habitat shapes connectivity for the target species and the development of models predicting connectivity through the seascape. On land, these sorts of predictions fall under the umbrella of landscape genetics (Manel et al., 2003; Manel and Holderegger, 2013). Seascape genetics, however, has thus far focused nearly exclusively on modeling larval connectivity using biophysical and oceanographic models (Sponaugle et al., 2002; Selkoe et al., 2008; Galindo et al., 2010). Little effort has been placed on modeling connectivity in adult dispersers, and is so far limited to a handful of studies of apex predators (Schultz et al., 2008; Amaral et al., 2012; Lowther et al., 2012). This dearth of information persists despite the fact that many coral reef organisms without larval dispersal are habitat specialists (for example, gray reef sharks, whitetip reef sharks, olive sea snakes, blue spotted fantail ray) and habitat is likely to have a much stronger influence on their dispersal than oceanographic features.

A key element will be the development of models that test specific hypotheses on how habitat shapes connectivity. Models based on Circuit Theory (such as Isolation-by-Resistance; IBR) and Least Cost Path (LCP) (McRae, 2006; McRae and Beier, 2007; McRae et al., 2008) have been successfully used to predict connectivity on land, but their application in marine systems has been largely overlooked. For adult dispersers with specialized habitat requirements, we need to determine whether habitat features are more likely to influence dispersal than oceanographic currents. For example, three environmental variables, distance from the coast, latitude and coral cover, effectively explained much of the differences in abundance of reef associated sharks across the largest network of MPAs in the world, the GBR Marine Park, Australia (Espinoza et al., 2014). Similarly, gray reef sharks have been shown to favor offshore areas with high coral cover (Fernandes et al., 2005) and, within reefs, they prefer sharp dropoffs over reef slopes (Rizzari et al., 2014). All of these habitat features could be easily included in IBR and LCP models.

Connectivity models incorporate preexisting ecological data, for example patterns of presence/absence, abundance and habitat use, to develop 'resistance surfaces' that describe the relative probability of an animal moving through different seascape features (for example, coral reefs vs. mud flats vs. seagrass beds). These resistance surfaces represent hypothetical relationships between the connectivity of target species and habitat features. The predictions of these models can then be tested using either genetic (McRae, 2006) or empirical data on animal movements (Desrochers et al., 2011; St-Louis et al., 2014). This approach has the capacity to describe patterns of connectivity through the seascape, and in so doing, identify key areas for protection. 


\section{CONCLUSION}

Networks of MPAs have transformed our ability to conserve our most precious marine habitats, but are not yet a panacea for biodiversity conservation. Species with sedentary juvenile stages and adult dispersal phases may still be poorly protected due to movement occurring outside of no take areas, or be constrained by limited connectivity. A potential solution may be to adopt conservation management strategies tried and tested for terrestrial organisms. Recent technological and analytical advances allow us to identify seascape features that facilitate connectivity. Protection for identified corridors may effectively conserve many of those organisms that are key to coral reef ecological function, but as yet not well protected by existing MPA networks.

\section{REFERENCES}

Almany, G., Connolly, S., Heath, D., Hogan, J., Jones, G., McCook, L., et al. (2009). Connectivity, biodiversity conservation and the design of marine reserve networks for coral reefs. Coral Reefs 28, 339-351. doi: 10.1007/s00338-009-0484-x

Almany, G. R., Berumen, M. L., Thorrold, S. R., Planes, S., and Jones, G. P. (2007). Local replenishment of coral reef fish populations in a marine reserve. Science 316, 742-744. doi: 10.1126/science. 1140597

Amaral, A. R., Beheregaray, L. B., Bilgmann, K., Boutov, D., Freitas, L., Robertson, K. M., et al. (2012). Seascape genetics of a globally distributed, highly mobile marine mammal: the short-beaked common dolphin (genus Delphinus). PLoS ONE 7:e31482. doi: 10.1371/journal.pone.0031482

Barnett, A., Abrantes, K. G., Seymour, J., and Fitzpatrick, R. (2012). Residency and spatial use by reef sharks of an isolated seamount and its implications for conservation. PLoS ONE 7:e36574. doi: 10.1371/journal.pone.0036574

Boyle, P. R. (1990). Cephalopod biology in the fisheries context. Fish. Res. 8, 303-321. doi: 10.1016/0165-7836(90)90001-C

Burns, G., and Heatwole, H. (1998). Home range and habitat use of the olive sea snake, Aipysurus laevis, on the Great Barrier Reef, Australia. J. Herpetol. 32, 350-358. doi: 10.2307/1565449

Cressey, D. (2011). Uncertain sanctuary. Nature 480, 166-167. doi: 10.1038/480166a

Desrochers, A., Bélisle, M., Morand-Ferron, J., and Bourque, J. (2011). Integrating GIS and homing experiments to study avian movement costs. Landsc. Ecol. 26, 47-58. doi: 10.1007/s10980-0109532-8

Edgar, G. J., Stuart-Smith, R. D., Willis, T. J., Kininmonth, S., Baker, S. C., Banks, S., et al. (2014). Global conservation outcomes depend on marine protected areas with five key features. Nature 506, 216-220 doi: 10.1038/nature13022

Espinoza, M., Cappo, M., Heupel, M. R., Tobin, A. J., and Simpfendorfer, C. A. (2014).
Quantifying shark distribution patterns and species-habitat associations: implications of Marine Park Zoning. PLoS ONE 9:e106885. doi: 10.1371/journal.pone.0106885

Espinoza, M., Heupel, M. R., Tobin, A., and Simpfendorfer, C. (2015). Residency patterns and movements of grey reef sharks (Carcharhinus amblyrhynchos) in semi-isolated coral reef habitats. Mar. Biol. 162, 343-358. doi: 10.1007/s00227014-2572-x

Fernandes, L., Day, J., Lewis, A., Slegers, S., Kerrigan, B., Breen, D., et al. (2005). Establishing representative no-take areas in the Great Barrier Reef: large-scale Implementation of theory on marine protected areas. Conserv. Biol. 19, 1733-1744. doi: 10.1111/j.1523-1739.2005.00302.x

Field, I., Meekan, M., Speed, C., White, W., and Bradshaw, C. (2011). Quantifying movement patterns for shark conservation at remote coral atolls in the Indian Ocean. Coral Reefs 30, 61-71. doi: 10.1007/s00338-010-0699-x

Friedlander, A. M., Caselle, J. E., Ballesteros, E., Brown, E. K., Turchik, A., and Sala, E. (2014). The real Bounty: marine biodiversity in the Pitcairn Islands. PLoS ONE 9:e100142. doi: 10.1371/journal.pone.0100142

Fry, G., Milton, D., and Wassenberg, T. (2001). The reproductive biology and diet of sea snake bycatch of prawn trawling in northern Australia: characteristics important for assessing the impacts on populations. Pac. Conserv. Biol. 7, 55.

Galindo, H. M., Pfeiffer-Herbert, A. S., McManus, M. A., Chao, Y. I., Chai, F. E. I., and Palumbi, S. R. (2010). Seascape genetics along a steep cline: using genetic patterns to test predictions of marine larval dispersal. Mol. Ecol. 19, 3692-3707. doi: 10.1111/j.1365-294X.2010.04694.x

Gerlach, G., Atema, J., Kingsford, M. J., Black, K. P., and Miller-Sims, V. (2007). Smelling home can prevent dispersal of reef fish larvae. Proc. Natl. Acad. Sci. U.S.A. 104, 858-863. doi: 10.1073/pnas.0606777104

Gredzens, C., Marsh, H., Fuentes, M. M., Limpus, C. J., Shimada, T., and Hamann, M. (2014). Satellite tracking of sympatric marine megafauna can inform the biological basis for species co-management. PLoS ONE 9:e98944. doi: 10.1371/journal.pone.0098944

Harrison, H. B., Williamson, D. H., Evans, R. D., Almany, G. R., Thorrold, S. R., Russ, G. R., et al. (2012). Larval export from marine reserves and the recruitment benefit for fish and fisheries. Curr. Biol. 22, 1023-1028. doi: 10.1016/j.cub.2012.04.008

Hays, G. C., Mortimer, J. A., Ierodiaconou, D., and Esteban, N. (2014). Use of long-distance migration patterns of an endangered species to inform conservation planning for the world's largest marine protected area. Conserv. Biol. 28, 1636-1644. doi: 10.1111/cobi.12325

Heithaus, M. R., Alcoverro, T., Arthur, R., Burkholder, D. A., Coates, K. A., Christianen, M. J., et al. (2014). Seagrasses in the age of sea turtle conservation and shark overfishing. Mar. Ecosyst. Ecol. 1:28. doi: 10.3389/fmars.2014.00028

Heupel, M. R., Simpfendorfer, C. A., and Fitzpatrick, R. (2010). Large-scale movement and reef fidelity of grey reef sharks. PLoS ONE 5:e9650. doi: 10.1371/journal.pone.0009650
Hoegh-Guldberg, O., Mumby, P., Hooten, A., Steneck, R., Greenfield, P., Gomez, E., et al. (2007). Coral reefs under rapid climate change and ocean acidification. Science 318, 1737-1742. doi: 10.1126/science. 1152509

Hooker, S. K., Cañadas, A., Hyrenbach, K. D. Corrigan, C., Polovina, J. J., and Reeves, R. R. (2011). Making protected area networks effective for marine top predators. Endanger. Species Res. 13, 203-218. doi: 10.3354/esr00322

Hughes, T. P., Baird, A. H., Bellwood, D. R., Card, M., Connolly, S. R., Folke, C., et al. (2003). Climate change, human impacts, and the resilience of coral reefs. Science 301, 929-933. doi: 10.1126/science. 1085046

Hughes, T. P., Rodrigues, M. J., Bellwood, D. R., Ceccarelli, D., Hoegh-Guldberg, O., McCook, L., et al. (2007). Phase shifts, herbivory, and the resilience of coral reefs to climate change. Curr. Biol. 17, 360-365. doi: 10.1016/j.cub.2006.12.049

Jones, G., Almany, G., Russ, G., Sale, P., Steneck, R., Van Oppen, M., et al. (2009). Larval retention and connectivity among populations of corals and reef fishes: history, advances and challenges. Coral Reefs 28, 307-325. doi: 10.1007/s00338-009-0469-9

Jones, G. P., Srinivasan, M., and Almany, G. R. (2007). Population connectivity and conservation of marine biodiversity. Oceanography 20, 100-111. doi: 10.5670/oceanog.2007.33

Last, P. R., and Stevens, J. D. (2009). Sharks and Rays of Australia, 2nd Edn. Collingwood, VIC: CSIRO.

Lee, K. A., Huveneers, C., Macdonald, T., and Harcourt, R. G. (2014). Size isn't everything: movements, home range, and habitat preferences of eastern blue gropers (Achoerodus viridis) demonstrate the efficacy of a small marine reserve. Aquat. Conserv. doi: 10.1002/aqc.2431. [Epub of print].

Lowther, A. D., Harcourt, R. G., Goldsworthy, S. D., and Stow, A. (2012). Population structure of adult female Australian sea lions is driven by fine-scale foraging site fidelity. Anim. Behav. 83, 691-701. doi: 10.1016/j.anbehav.2011.12.015

Manel, S., and Holderegger, R. (2013). Ten years of landscape genetics. Trends Ecol. Evol. 28, 614-621. doi: 10.1016/j.tree.2013.05.012

Manel, S., Schwartz, M. K., Luikart, G., and Taberlet, P. (2003). Landscape genetics: combining landscape ecology and population genetics. Trends Ecol. Evol. 18, 189-197. doi: 10.1016/S01695347(03)00008-9

McCook, L. J., Ayling, T., Cappo, M., Choat, J. H., Evans, R. D., De Freitas, D. M., et al. (2010). Adaptive management of the Great Barrier Reef: a globally significant demonstration of the benefits of networks of marine reserves. Proc. Natl. Acad. Sci. U.S.A. 107, 18278-18285. doi: 10.1073/pnas.0909335107

McRae, B. H. (2006). Isolation by resistance. Evolution 60, 1551-1561. doi: 10.1111/j.0014-3820.2006. tb00500.x

McRae, B. H., and Beier, P. (2007). Circuit theory predicts gene flow in plant and animal populations. Proc. Natl. Acad. Sci. U.S.A. 104, 19885-19890. doi: 10.1073/pnas.0706568104

McRae, B. H., Dickson, B. G., Keitt, T. H., and Shah, V. B. (2008). Using circuit theory to model connectivity in ecology, evolution and conservation. Ecology 89, 2712-2724. doi: 10.1890/07-1861.1 
Pala, C. (2013). Giant marine reserves pose vast challenges. Science 339, 640-641. doi: 10.1126/science.339.6120.640

Pendoley, K. L., Schofield, G., Whittock, P. A., Lerodiaconou, D., and Hays, G. C. (2014). Protected species use of a coastal marine migratory corridor connecting marine protected areas. Mar. Biol. 161, 1455-1466. doi: 10.1007/s00227014-2433-7

Planes, S., Jones, G. P., and Thorrold, S. R. (2009). Larval dispersal connects fish populations in a network of marine protected areas. Proc. Natl. Acad. Sci. 106, 5693-5697. doi: 10.1073/pnas.0808007106

Rizzari, J. R., Frisch, A. J., and Magnenat, K. A. (2014). Diversity, abundance, and distribution of reef sharks on outer-shelf reefs of the Great Barrier Reef, Australia. Mar. Biol. 161, 2847-2855. doi: 10.1007/s00227-014-2550-3

Ruppert, J. L., Travers, M. J., Smith, L. L., Fortin, M.-J., and Meekan, M. G. (2013). Caught in the middle: combined impacts of shark removal and coral loss on the fish communities of coral reefs. PLoS ONE 8:e74648. doi: 10.1371/journal.pone. 0074648

Russ, G. R., and Zeller, D. C. (2003). From mare liberum to mare reservarum. Mar. Pol. 27, 75-78. doi: 10.1016/S0308-597X(02)00054-4

Sandin, S. A., Smith, J. E., Demartini, E. E., Dinsdale, E. A., Donner, S. D., Friedlander, A. M., et al. (2008). Baselines and degradation of coral reefs in the Northern Line Islands. PLoS ONE 3:e1548. doi: 10.1371/journal.pone.0001548
Schultz, J., Feldheim, K., Gruber, S., Ashley, M., McGovern, T., and Bowen, B. (2008). Global phylogeography and seascape genetics of the lemon sharks (genus Negaprion). Mol. Ecol. 17, 5336-5348. doi: 10.1111/j.1365-294X.2008. 04000.x

Selkoe, K. A., Henzler, C. M., and Gaines, S. D. (2008). Seascape genetics and the spatial ecology of marine populations. Fish. Fish. 9, 363-377. doi: 10.1111/j.1467-2979.2008.00300.x

Sponaugle, S., Cowen, R. K., Shanks, A., Morgan, S. G., Leis, J. M., Pineda, J., et al. (2002). Predicting self-recruitment in marine populations: biophysical correlates and mechanisms. Bull. Mar. Sci. 70, 341-375.

St-Louis, V., Forester, J. D., Pelletier, D., Bélisle, M., Desrochers, A., Rayfield, B., et al. (2014). Circuit theory emphasizes the importance of edgecrossing decisions in dispersal-scale movements of a forest passerine. Landsc. Ecol. 29, 831-841. doi: 10.1007/s10980-014-0019-x

Tittensor, D. P., Mora, C., Jetz, W., Lotze, H. K., Ricard, D., Berghe, E. V., et al. (2010). Global patterns and predictors of marine biodiversity across taxa. Nature 466, 1098-1101. doi: 10.1038 /nature09329

Voris, H. K., and Jayne, B. C. (1979). Growth, reproduction and population structure of a marine snake, Enhydrina schistosa (Hydrophiidae). Copeia. 1979, 307-318. doi: 10.2307/1443419

Ward, T. (2001). Age structures and reproductive patterns of two species of sea snake, Lapemis hardwickii Grey (1836) and Hydrophis elegans (Grey
1842), incidentally captured by prawn trawlers in northern Australia. Mar. Freshw. Res. 52, 193-203. doi: 10.1071/MF00025

Zeller, D. C., and Russ, G. R. (1998). Marine reserves: patterns of adult movement of the coral trout (Plectropomus leopardus (Serranidae)). Can. J. Fish. Aquat. Sci. 55, 917-924. doi: 10.1139/ f97-311

Conflict of Interest Statement: The authors declare that the research was conducted in the absence of any commercial or financial relationships that could be construed as a potential conflict of interest.

Received: 09 December 2014; accepted: 16 February 2015; published online: 03 March 2015.

Citation: Momigliano P, Harcourt R and Stow A (2015) Conserving coral reef organisms that lack larval dispersal: are networks of Marine Protected Areas good enough? Front. Mar. Sci. 2:16. doi: 10.3389/fmars. 2015.00016

This article was submitted to Marine Megafauna, a section of the journal Frontiers in Marine Science. Copyright (c) 2015 Momigliano, Harcourt and Stow. This is an open-access article distributed under the terms of the Creative Commons Attribution License (CC BY). The use, distribution or reproduction in other forums is permitted, provided the original author(s) or licensor are credited and that the original publication in this journal is cited, in accordance with accepted academic practice. No use, distribution or reproduction is permitted which does not comply with these terms. 